\title{
Productivity as a value parameter for FM and CREM
}

\author{
Jensen, Per Anker; van der Voordt, Theo
}

Published in:

Facilities

Link to article, DOI:

10.1108/F-04-2020-0038

Publication date:

2021

Document Version

Peer reviewed version

Link back to DTU Orbit

Citation (APA):

Jensen, P. A., \& van der Voordt, T. (2021). Productivity as a value parameter for FM and CREM. Facilities, 39(5/6), 305-320. https://doi.org/10.1108/F-04-2020-0038

\section{General rights}

Copyright and moral rights for the publications made accessible in the public portal are retained by the authors and/or other copyright owners and it is a condition of accessing publications that users recognise and abide by the legal requirements associated with these rights.

- Users may download and print one copy of any publication from the public portal for the purpose of private study or research.

- You may not further distribute the material or use it for any profit-making activity or commercial gain

- You may freely distribute the URL identifying the publication in the public portal

If you believe that this document breaches copyright please contact us providing details, and we will remove access to the work immediately and investigate your claim 


\title{
PRODUCTIVITY AS A VALUE PARAMETER FOR FM AND CREM
}

\author{
Per Anker Jensen \\ Department of Management Engineering, Technical University of Denmark, Kongens Lyngby, Denmark
}

Theo J.M. van der Voordt

Department of Management in the Built Environment, Faculty of Architecture, Delft University of Technology, Delft, The Netherlands, and Center for People and Buildings, Delft, the Netherlands

To be cited as: Jensen, P.A. and Van der Voordt, T. (2020), Productivity as a Value Parameter for FM and CREM. Facilities. Forthcoming. Post-print accepted 17-07-2020. DOI 10.1108/F-04-2020-0038

The full text of this Author Accepted Manuscript (AAM) may become visible within our personal website, institutional repository (IR), subject repository, SCN signed up to the Voluntary STM Sharing Principles as soon as the final version has been published in the journal, according to the Creative Commons Attribution Non-commercial International Licence 4.0 (CC BY-NC 4.0). Any reuse is allowed in accordance with the terms outlined by the licence. To reuse the AAM for commercial purposes, permission should be sought by contacting permissions@emeraldinsight.com.

\begin{abstract}
Purpose: To investigate how Facilities Management (FM) and Corporate Real Estate Management (CREM) can add value to organisations by contributing to improved productivity of knowledge workers, and to explore interrelationships between productivity, employee satisfaction, and other value parameters.

Methodology: A literature research of possible contributions of FM and CREM to improved labour productivity in relation to five activity areas of FM/CREM (portfolio management, project management, space and workplace management, property management, and service management) and a first exploration of interrelationships between productivity and other value parameters.

Findings: The findings indicate that FM and CREM most directly can contribute to productivity by space and workplace management that supports different types of work and organisational activities. Portfolio and project management can mostly contribute by providing appropriate locations, adjacency relations between different parts of the organisation, and supporting process flow and logistics. Property management can contribute to productivity by ensuring business continuity and comfortable indoor climate. Service management can contribute by relieving staff from trivial tasks by efficient services and by providing exiting experiences. Productivity shows to be mainly positively related to satisfaction; insights into interrelationships with other value parameters are still limited.

Implications: The results can be used to obtain a deeper understanding of how FM and CREM can add value to organisations by contributing to improved labour productivity. Practitioners can find inspiration on how to contribute to labour productivity and additional benefits within specific activity areas of FM and CREM. The exploration of interrelationships between productivity and other values can be used as input to a future research agenda.
\end{abstract}


Originality: The paper adds new insights to the growing body of knowledge about how FM/CREM can contribute to increased labour productivity and how other value parameters may be interrelated with productivity.

Keywords: Facilities Management, Corporate Real Estate Management, productivity, value parameters, added value, interrelationships

Paper type: Literature review

\section{Introduction}

The added value of Facilities Management (FM) and Corporate Real Estate Management (CREM) has received increased attention in research and practice. Earlier research has shown that practitioners regard productivity to be one of the most important value parameters, but need a better understanding of the impact of the work environment and how to manage and measure productivity (Jensen and van der Voordt, 2017). Productivity can both concern the productivity of FM and CREM providers, as internal department and part of the organisation or as external service provider, and the impact of FM and CREM on the productivity of employees, business units and the organisation as a whole (Bröchner, 2017). This paper focuses on the latter and searches for answers to the research question: how can FM and CREM contribute to improved productivity of knowledge workers and as such add value to organisations?

The impact of FM/CREM on labour productivity will be discussed in relation to five activity areas of FM and CREM. These activity areas were defined together with a group of practitioners and a consulting group based on a classification in a textbook (Jensen, 2008):

1. Portfolio management: managing real estate portfolios

2. Project management: managing building projects from initiation till delivery

3. Space and workplace management: managing space allocation and workplace design

4. Property management: managing operation and maintenance of buildings-in-use

5. Service management: managing support services

The boundaries between these areas are not always sharp. For instance, management activities are often ongoing processes but can also regard a project, from a start moment to a clearly defined end. The main difference between the five activity areas is the scale level, ranging from portfolio and buildings as a whole to spaces and services, whereas property management focuses on buildings-in-use. In another context, property management also refers to acquisition, exploitation and disposal of buildings from an investor's point of view.

The paper further explores the interrelationships between productivity and various other value parameters. All findings are based on a narrative literature review of FM and CREM related publications, using a structured approach according to Webster and Watson (2002). The review covers the last five volumes of leading journals in the field such as Facilities, the Journal of Facilities Management and the Journal of Corporate Real Estate, additional publications and related references. 


\section{The concept of productivity}

Productivity is an essential concept for all production processes, and an important issue in macroeconomics. Productivity is a measure for output in relation to input and can been calculated by the formula: Productivity = Output/Input. Harris (2019) defines productivity as maximizing output with minimum effort or expense, while succeeding in producing the desired results. Economists make a distinction between multi-factor or total factor productivity as the ratio between the total output and total input, and partial productivity that regards a particular part of the input, i.e. production factors such as labour, capital, information, technology (ICT etc.), company infrastructure (buildings, facilities, services), and natural resources such as land, energy and raw materials (OECD, 2001; Frankema, 2003).

It is also important to distinguish between individual labour productivity, the productivity on different organisational levels such as teams, departments and the company as a whole, and productivity on industry level (De Been et al., 2017; Bröchner, 2017). Initiatives to increase knowledge sharing may result in a decrease in the perceived individual productivity and at the same time result in an increase in the organisational productivity (Mosbech, 2004). Therefore, it is relevant to collect information on productivity among staff members and managers on different organizational levels.

\section{The business impact of productivity}

Higher productivity has a disproportionate impact on organizational performance compared to property cost savings (Palvalin et al., 2017). Improved productivity occurs, when the change in output from year to year is higher than the change in input (De Been et al., 2017). If the output increases without a change in input, then it will - with anything else being equal - lead to increased turnover, and thereby have a direct effect on the top line of the company. If output is not changed and input is reduced, then it will - with anything else being equal - lead to reduced production costs. Improved productivity will lead to increased profitability and competitiveness, and thereby has a direct effect on the bottom line of the company, unless competitors increase their productivity to the same degree. In any case, improved productivity is decisive for sustaining competitiveness.

\section{Labour productivity and motivation}

FM/CREM is often perceived as something that just needs to function well to avoid staff becoming unsatisfied. As such, FM/CREM is a hygiene factor according to the motivation theory by Herzberg (1968). Hygiene factors are factors, which have a negative impact on motivation, if they are not present, but they cannot contribute to motivation. As an appropriate hygiene factor, FM/CREM creates value for the company by avoiding dissatisfaction and lack of motivation and as such by preventing loss of productivity. However, there are opportunities for FM/CREM to act as a motivation factor as well and as such to contribute to improved productivity. For instance by creating attractive and high-performing physical facilities and services that help to attract and retain talented staff and support the effectiveness and efficiency of office work.

Martijn et al. (2018) presents a literature review on cleaning, which includes several sources that discuss whether cleaning is only a hygiene factor or can also be a motivation factor. They write: "When cleanliness is as expected, the confirmation of expectations influences perceptions or satisfaction neither positively nor negatively. When cleanliness of an environment is better than 
expected, the perception will be positive and will, thus, lead to satisfaction. When cleanliness is poorer than expected, cleanliness is a hygiene factor that may cause dissatisfaction."

Research by Haynes (2007a,b) shows that the behavioural environment (communication and concentration i.e. how well occupiers connect with each other and the impact of the office environment on their behaviour) has more influence on labour productivity than the physical environment (office layout and comfort i.e. how well occupiers physically connect to their office environment).

In the pyramid of needs in the motivation theory by Maslow (1943), esteem and self-actualization constitutes the two top levels. The responsibility for that mainly lies at the top management, the human resource department and the managers in the core business organisation. FM can mostly influence the three bottom levels consisting of physiological needs and needs for safety and belonging. However, FM can have a certain influence on the top levels as well, through facilitating and supporting esteem and self-actualisation, in collaboration with other support functions like Human Resource and IT. For instance, by creating an attractive work environment with a high experience value that evokes an image among staff and visitors of being highly valued by the organisation (see for instance Pine and Gilmore, 1999).

\section{Measuring productivity - problems and solutions}

Within economics, productivity is measured as the economic value of the produced products, for instance by their sales value, divided by the resources used in the production process (OECD, 2001). In production and operation management, productivity can be measured in physical units, for instance the number of products produced, divided by the number of staff involved in the production measured as full time equivalents, number of work hours or labour cost (Taylor, 1911).

Bröchner (2017) presents a literature review of the challenges faced by productivity measurement in the service sector. His paper focuses on the productivity of FM providers on the industry level and the firm level. The intangible and heterogeneous nature of services and a production process that is interactive with the customer being an active participant makes it difficult to measure both outputs and inputs. Bröchner refers to the OECD manual on measuring productivity (OECD, 2001) that suggests to measure labour productivity on industry level as the gross value added at basic prices and constant prices per hour worked, based on market prices for both inputs and outputs and relying on Annual Business Surveys. However, quality changes in outputs as well as in inputs are also important but often difficult to determine for services. Based on a comparison of productivity measuring in various studies, Bröchner suggests to incorporate co-production with clients and effects of client satisfaction, considering productivity effects on both providers and clients jointly. Inputs stemming from clients considered as resources for the FM firm could be based on reports of client time spent on interaction, categorized according to staff skill levels.

To measure the productivity of office workers and in particular knowledge workers on individual, team and organizational level is also difficult, because the output is diverse and often not easy to quantify (De Been et al., 2017). Therefore, it is common to measure productivity as the perceived productivity, i.e. the individual staff members' own perception of output seen in relation to the perception of input. This is obviously subjective and thus uncertain. Besides, this dependence on 
self-reporting leads to another validity problem, as the relation between objective and subjective measures of performance is not very strong (Bommer et al., 1995). However, by measuring with the same methods for a larger group and at different times, useful information can be collected on variations and trends in the productivity for knowledge workers.

Based on literature from different fields (environmental psychology, corporate and public real estate management, facility management, business administration) and explorations by Van der Voordt (2003) and Sullivan et al. (2013), De Been et al. (2017) present a summary of various ways to measure the productivity of knowledge workers, see Table 1.

Table 1: Ways to measure the productivity of knowledge workers (De Been et al., 2017)

- Actual output versus actual input. For example:

- The number of translated words per team or per employee per unit of time (translation agency), the number of phone calls per day (call centre), or the number of manufactured products per full time equivalent in the industry sector.

- The impact of facilities on the outcomes of cognitive performance tests (e.g. working memory, processing speed, concentration).

- Actual input, for example monitoring computer activity (keystrokes, mouse clicks) that is used to produce the output.

- Amount of time spent or saved, for instance the amount of time gained by implementing a new computer system that works faster or the amount of time lost by having to log on frequently to a time consuming computer system.

- Absenteeism due to illness or other reasons and as such being non-productive, or the opposite: presence. Connected topics include the reported frequency of health issues.

- Satisfaction, based on the assumption that a happy worker is a productive worker. Connected topics include job satisfaction, job engagement, satisfaction with facilities, or the intention to stay or to quit.

- Perceived productivity support, i.e. the perceived support of productivity by the current work environment, measured on a Likert scale, the estimated percentage of time being productive, the perceived productivity gain when all facilities would be excellent, or the perceived increase or loss of productivity after a change.

- Indirect indicators, for instance the extent to which people are able to concentrate properly, the frequency of being actually distracted, the easiness with which employees can solve a problem, or the lack of knowledge through insufficient interaction with colleagues.

In order to be able to benchmark productivity data within one's own organization (e.g. between different business units, or over time) and between other organizations, De Been et al. (2017) propose to use a limited number of KPI's for measuring productivity, by asking to what extent the work environment and facilities support the following activities (scores on a 5-point scale, ranging from 1 - very unsupportive, to 5 - very supportive): 
- Focused concentrated work

- Knowledge sharing

- Social interaction

- Individual productivity

- Team productivity

This list could be extended with questions regarding the perceived productivity support by particular environmental factors such as the indoor climate, personal control, ergonomics, IT facilities and interior design .If possible, the subjective measurement of productivity should be completed with objective measures like those mentioned in Table 1.

\section{Potential contributions to productivity by different FM/CREM activity areas}

The following sub-sections investigate how the five different activity areas in FM/CREM may contribute to productivity.

\subsection{Portfolio management}

In the 2015 global Corporate Real Estate (CRE) trends survey, $75 \%$ of the respondents stated that there is an increasing demand for CRE to enhance the productivity of the real estate portfolio (Yang et al., 2015). By development of a property portfolio, FM/CREM can contribute to productivity by appropriate location of the corporate facilities in relation to customers, staff, collaboration partners and/or traffic infrastructure (Haynes et al., 2017). Companies within the same industry are often located in clusters, for instance near institutions like universities, which they all draw on to get knowledge and new staff (Porter, 2016). Business campuses can also work as a catalyst for knowledge sharing and innovation (Curvelo Magdaniel et al., 2018; Weijs-Perrée, 2019), which may lead to increased productivity and higher competitive power. Another important factor is to create appropriate adjacency relationships internally in large companies and corporations, so that collaborative relations and process flow across facilities are supported (Haynes et al., 2017).

\subsection{Project management}

For building projects, the same aspects concerning location and adjacency relationships mentioned in section 4.1 are relevant as well. On building level, it is essential to ensure appropriate relationships and process flow internally in each building with short walking and transport distances (Haynes et al., 2017). Establishing appropriate infrastructure and technology is equally important (Nielsen, 2019). Chadburn et al. (2017) undertook a survey of 213 employees in eight financial and professional services firms in central London. Their findings showed that comfort, convenience, IT connectivity, good design and working to a specific time scale were strong drivers of personal productivity.

Providing a comfortable indoor climate is important to ensure labour productivity (Horr et al., 2016; Clements-Croome, 2018). Research by the World Green Building Council (WGBC) has documented that an inappropriate indoor climate reduces productivity, in particular with respect to air quality, thermal comfort and noise. Better air quality can improve employee productivity by 
$8-11 \%$, whereas the right temperature can make a difference of 4-6\%. Based on a review of 20 years of thermal comfort research, office worker's performance may even drop by $66 \%$ when exposed to distracting noise (Alker et al., 2014). De Dear et al. (2013) concluded that indoor thermal environments affect physiological thermoregulation and psychological processes involved in thermal comfort, which may in turn affect performance of certain tasks.

Fassoulis and Alexopoulos (2015) looked at the impact of workplace attributes on satisfaction and perceived productivity. Indoor climate showed to be more important for satisfaction and productivity among university management staff than premises management attributes such as cleanliness and fire safety. The possibility of personal control with one's own indoor climate is also important for staff not being dissatisfied (De Been et al., 2017). Boerstra et al. (2014) found a 6-10\% higher perceived productivity, when full personal control is experienced, compared to no control at all. The possibility to open windows is a basic element in this, but it also includes possibilities to control light level, sun shading, temperature, and air quality. This is, however, a challenge with modern office buildings, which usually are designed with open spaces with several workplaces.

\subsection{Space/workplace management}

For the design and management of an appropriate layout of workplaces it is important to clarify the different needs and work styles of the employees and the changes that for instance new technology are expected to involve (Haynes et al., 2017). This can be done in an appropriate briefing process (Van Meel and Stordal, 2017). For instance, in case of a financial institution with customer service on site it might be appropriate that branch offices are organised with a zoning divided in private (backstage), privileged (customer invited access) and public (frontstage) as investigated by Ekstrand and Damman (2016). For organisations with a combination of physical and virtual collaboration, the layout and technology for meeting rooms with advanced conference and audio-visual equipment might be of particular importance (Jensen and Nielsen, 2020).

There is quite some empirical data showing that the office layout and appropriate facilities may enhance or hinder individual, team and organisational productivity (Harris, 2019). Brill and Weidemann (2001) analysed a dataset with 13,000 respondents and concluded that the physical workplace contributes $5 \%$ to individual performance and $11 \%$ to team performance. The largest impact on performance and satisfaction are the ability to work distraction-free (solo or in groups), and) the possibilities for interaction with co-workers (especially spontaneous interaction, but also in meeting rooms). Based on 30 case studies, Kaczmarczyk et al. (2001) found productivity improvements of $2-58 \%$ after the introduction of teleworking, $15 \%$ due to high quality design, $22 \%$ due to ergonomic furniture, $9-13 \%$ due to high quality lighting and $7-10 \%$ due to noise reduction. A survey by Gensler (2005) identified a perceived potential of $19 \%$ productivity increase by a better working environment. Von Felten et al. (2015) found a significant perceived productivity gain, when all facilities would be excellent. In particular designing workplaces with less distraction and better ICT facilities (hard- and software) would be cost effective.

A Dutch survey among 7,000 respondents showed that satisfaction with the possibilities to concentrate at work is the most important predictor of perceived individual productivity support, whereas satisfaction with communication possibilities is the most important predictor for perceived support of team productivity (Maarleveld and De Been, 2011). This is in line with 
research by Olson (2002), who collected survey responses from 13,000 workers in the USA. He found that the workplace quality with the strongest impact on its occupants is the ability to do distraction-free solo work. The second most influencing workplace quality is support for impromptu interactions, because people learn particularly from informal interactions. Yunus and Ernawati (2018) found that both collaboration and privacy exert a positive influence on work productivity.

The need for collaboration and the need for privacy and concentration may evoke a tension, because other people's conversations are the main interference with distraction-free working and interrupt people's 'flow' (Olson, 2002). Working in an open setting often leads to distraction and disruption, resulting in lower perceived productivity support, particularly when conducting work that requires concentration and when doing creative work on one's own (Oseland et al., 2011). Brill et al. (2001) found that in open plan offices $65 \%$ of their respondents marked to be frequently distracted, versus 52\% in double-rooms and 29\% in single-rooms. Based on responses from 1,241 respondents from five different organisations, Seddigh et al. (2014) found that employees working in cell offices reported less distraction and stress than in five other office types. Employees working in flex offices reported less distraction and stress than in open plan offices. However, more open settings with short sight lines and distances to colleagues support knowledge sharing (Appel-Meulenbroek, 2014). This may explain why the latest survey by Gensler (2019) among 6,000 people working full time across the USA showed that only $7 \%$ preferred a fully open office setting and also a minority (16\%) preferred a totally private, enclosed, individual work environment for everyone. Over two-thirds (77\%) consider environments that fall between these extremes to be ideal. Remarkably, offices that have adopted activity-based workplaces (ABW) concept i.e. sharing a variety of task-related workplaces do not perform better on perceived productivity support.

The 2018 data from the Delft Centre for People and Buildings (not published) - based on the socalled WODI diagnostic workplace evaluation tool with responses from 30,191 respondents and 151 different projects - showed higher dissatisfaction with perceived support of one's own productivity support among office workers in activity based offices (31\%) compared to employees working in traditional offices with personal desks (18\%). For perceived support of team productivity the figures are respectively $27 \%$ and $17 \%$. Though space-per-employee has been reduced in activity-based work environments, this has not affected employee performance negatively. However, distracting elements (e.g. interruptions, overcrowding and noise) do have a negative influence on employee performance (Mesthrige and Chiang, 2019).

With the increased extent of knowledge work, meetings have achieved increased importance and taken more varied forms, including widespread use of virtual meetings with participants located different places. Thus, there might be a need for a thorough analysis of the need for different types of meetings, which the company currently has and is expected to have in the future (Thorn, 2019). There is a trend that meetings no longer mostly serve exchange of information, planning and decision-making. Instead they increasingly have a productive character, for instance when participants meet in a specially designed meeting room to produce a concept or a product together with virtually participating colleagues and external specialists by use of advanced IT, audi-visual equipment, virtual conference facilities and access to real-time information (Jensen and Nielsen, 2020). 
The layout must also include appropriate furniture, which is designed ergonomically correct and suitable for different settings (Van Meel et al., 2010; Mahoney et al., 2015). If workplaces are going to be used by different people, then the work desks should be easily adaptable in height and chairs should be easily regulated to fit individual preferences. Workplaces need to be fitted with IT equipment suitable for the different functions, and meeting facilities should be fitted with AV equipment and virtual conference equipment. Common technical equipment like printers, copying machines as well as coffee facilities and break areas should be placed conveniently with consideration of reasonable walking distance from all workstations (max. $50 \mathrm{~m}$ is recommended) and social contact, including possibilities for chance encounters (Van Meel et al., 2010). Stimulation of physical motion can also be a consideration. Karakolis and Callaghan (2014) showed that implementing sit-stand workstations in an office environment likely results in lower levels of body discomfort and may also have a positive effect on performance.

It is also important that the design is architecturally attractive and creates a pleasant ambiance in accordance with corporate values and culture (Poursafar et al., 2019). There has been some research on the impact of colour in work areas and meeting rooms, but the evidence is ambiguous (Bakker et al., 2013). As a contrast, there is clear documentation that use of plants in work areas so-called 'biophilic design' - has a positive impact on the indoor climate in work areas (Smith and Pitt, 2009; Bakker and Van der Voordt, 2010).

\subsection{Property management}

A fundamental purpose of property management is to sustain the functionality of buildings, technical installations and infrastructure. This includes ensuring business continuity and keep the uptime of technical supply systems high (ISO 2012a,b). Risk management is an important mean to achieve this (Jensen and Redlein, 2017). Security and preparedness in relation to break-ins, accidents and terror attacks are also important elements. Maintenance activities and servicing technical installations should be planned, so that interruptions and disturbances of the core business activities are avoided as far as possible. Another area of responsibility of property management is ongoing monitoring and regulation of technical installations controlling the indoor climate to ensure sustaining an appropriate indoor environment. Rapid amendment of faults and changes of light bulbs etc. is an important ongoing operational task, which can contribute to limit distractions of the core business staff in their work (Jensen, 2008).

\subsection{Service management}

Support services can particularly contribute to productivity by relieving and support staff as much as possible in their work activities (Bröchner, 2016). This can be done by an efficient office support, where for instance printers and copying machines are constantly filled up with paper and with easy access to or quick delivery of office supplies. It can also include appropriate IT-support, of both hardware and software, support of mobility, service oriented reception, help to arrange meetings and travel as well as servicing meetings.

A good standard for cleaning is a clear hygiene factor, while for instance attractive food, access to

fitness facilities and exiting events can be motivation factors. Nowadays FM/CREM has increasingly to deal with creating interesting experiences (ISS, 2018). 


\section{Interrelationships between productivity and employee satisfaction}

It is a common assumption that satisfied workers are productive workers. According to Wright (2017), happy and healthy people are more productive and engaged than disaffected people that do the minimum on a daily basis. This is probably correct within certain limits, because if staff is satisfied due to too favourable labour conditions, then it might harm productivity by decreasing their motivation to do their utmost best. However, Van der Voordt et al. (2017, p. 67) concluded that "Although the relationship between employee satisfaction and labour productivity is not always statistically significant and can be interfered with by variables such as intrinsic motivation and competition with colleagues, various studies have confirmed that both constructs are correlated" (e.g. Zelenski et al., 2008; Halkos and Bousinakis, 2010; Fassoulis and Alexopoulos, 2015.

De Been and Beijer (2014) found that satisfaction with the organisation plays a more substantial role in the perceived productivity support of the work environment, than the office concept. Haapakangasa et al. (2018) found that satisfaction with the physical environment, privacy and communication had the strongest positive associations with self-rated productivity and well-being at work. Based on responses from 25,947 respondents and 191 organizations, Groen et al. (2020) found that $38 \%$ of the variation of office employees' satisfaction with self-assessed productivity support by the work environment could be explained by employee satisfaction with facilities, the organization, current work processes and personal- and job-related characteristics. The most important predictor showed to be employee satisfaction with facilities. Psychological aspects (opportunities to concentrate and to communicate, privacy, level of openness), and functionality, comfort and diversity of the workplaces are also very important.

Based on interviews, questionnaires and documentation before and after relocation to an activitybased flexible office, Rölfo (2018) found that perceived performance and employee satisfaction with the physical environment increased significantly. Process factors such as objectives, financial and time resources, employee participation and empowerment, and methodological approach contributed to the outcomes. In another study, employee surveys, measurements of indoor environmental quality (IEQ) and step-count monitoring before and after relocation from contemporary open-plan offices to activity-based work spaces (ABW) showed significantly higher satisfaction results on key IEQ dimensions, perceived productivity and health in the ABW offices (Candido et al., 2018). This research highlights the significance and impact of office layout and human-centred approach to design on occupants' satisfaction, perceived productivity and incidental physical activity opportunities. However, based on web-based surveys conducted before and after a company's short distance relocation, Nappi et al. (2020) found that employees experienced greater job stress and less workspace satisfaction and felt less attached to their workspaces, whereas the evaluations of workspace support to labour productivity did not change. Contrary to their expectations, employees' workspace satisfaction was not related to their evaluation of the workspace as supporting labour productivity. Instead, this relationship was moderated by job stress.

The findings confirm that employee satisfaction with buildings and facilities correlates significantly with perceived productivity support. However, the relationship is complex due to intermediating variables. Besides, it is difficult to evaluate, what is the cause and what is the effect. It might as well be assumed that productivity leads to employee satisfaction. According to Bakker 
(2014), being productive and attaining ones' personal or organisational objectives contributes to satisfaction and well-being. One argument for this is related to Maslow's pyramid of needs (Maslow, 1943). To be productive can lead to fulfilment of the two top levels: Esteem and selfactualization. The relationships can most likely be both ways.

\section{Interrelationships between productivity and innovation and creativity}

Productivity concerns the quantitative performance, while innovation and creativity is more related to qualitative aspects of development and performance. In the development of production processes, innovation and creativity can lead to increased productivity (Appel-Meulenbroek and Nardelli, 2016). When implemented successfully, innovations might be diffused to other similar processes in the company and the changed processes might trigger other innovations (Nardelli, 2017; Nardelli and Broumels, 2018).

De Paoli et al. (2017) analysed the images of the headquarters of allegedly 'creative workspaces' published on the Internet across a broad range of industries and corporations, in order to explore how these organisations try to enhance employee creativity, foster company innovation and communicate a positive company image. Their analysis shows that most designs follow standardized or stereotypical approaches to nurturing creativity: playfully or artistically designed open spaces, environments reminiscent of home, sports and play, nature, past/future technologies, or culturally aligned symbols. The images suggest that creativity flourishes in happy, relaxed and playful communities within close-knit teams. However, they also identified three contradictions: individually versus collectively produced creativity; professionally designed workspaces versus workspaces created through participation; and planned versus emerging creativity.

Leonard and Swap (2005) emphasized the importance of group creativity and innovation. Enabling creative processes require open communication channels among group members, well-designed places for brainstorming and noisy divergence, spaces for incubation and reflection, easily accessible and well-equipped meeting places for convergence, accessible information technology that links people and ideas, and a psychological environment that encourages risk-taking and failing forward. Barrett (2016) plead for designing physical workspaces that attract and retain a diverse workforce by accommodating employees equally, rather than on generational cohort membership. Sicotte et al. (2019) collected data on an enterprise's ten multidisciplinary teams operating in diverse workspaces by over 40 interviews, four months of observation, secondary data and a survey with 645 responses. They found that proximity in open space is paramount for teams co-located on site and abroad. The relationship between team effectiveness and team creativity showed to be strong and bidirectional.

\section{Exploration of interrelationships between productivity and other values}

Except for satisfaction and innovation and creativity addresses in the two previous sections, the relationships between productivity and other value parameters have not been investigated much and are consequently less clear. Table 2 presents examples of the potential effect of productivity on 11 other value parameters that were identified by Jensen and van der Vordt (2017), and vice versa, of these value parameters on productivity. Due to the limited evidence, these potential 
effects should mostly be regarded as propositions or hypotheses of assumed cause-effect relationships. A short indication of reason or example is included for each effect in the right column of the table.

Table 2. Examples of possible relationships between productivity and other value parameters

\begin{tabular}{|l|l|l|}
\hline $\begin{array}{l}\text { Value } \\
\text { parameter }\end{array}$ & $\begin{array}{l}\text { Effect on Productivity } \\
\text { Effect } \text { of Productivity }\end{array}$ & Reason/examples \\
Satisfaction & $\begin{array}{l}\text { On: Positive } \\
\text { Of: Positive }\end{array}$ & $\begin{array}{l}\text { Satisfied workers can be productive workers } \\
\text { Being productive can provide self-esteem }\end{array}$ \\
\hline Image & $\begin{array}{l}\text { On: Positive } \\
\text { Of: Positive }\end{array}$ & $\begin{array}{l}\text { By attracting and retaining productive staff } \\
\text { By supporting image of an efficient company }\end{array}$ \\
\hline Culture & $\begin{array}{l}\text { On: Positive } \\
\text { Of: Positive }\end{array}$ & $\begin{array}{l}\text { A lean culture supports productivity } \\
\text { Being productive can be part of identity }\end{array}$ \\
\hline $\begin{array}{l}\text { Health and } \\
\text { safety }\end{array}$ & $\begin{array}{l}\text { On: Positive } \\
\text { Of: Negative }\end{array}$ & $\begin{array}{l}\text { A healthy workforce can be productive } \\
\text { High intensity of work can create stress etc. }\end{array}$ \\
\hline Adaptability & $\begin{array}{l}\text { On: Positive } \\
\text { Of: Negative }\end{array}$ & $\begin{array}{l}\text { High adaptability can reduce downtime } \\
\text { High productivity can hinder adaptations }\end{array}$ \\
\hline creativity & $\begin{array}{l}\text { On: Positive } \\
\text { Of: Positive }\end{array}$ & $\begin{array}{l}\text { Innovations can lead to productivity increase } \\
\text { Improvements can be diffused in the company }\end{array}$ \\
\hline Risk & On: Positive & $\begin{array}{l}\text { Risk reduction can increase uptime } \\
\text { Novel methods might create new, unknown risks }\end{array}$ \\
\hline Cost & $\begin{array}{l}\text { On: Negative } \\
\text { Of: Positive/negative }\end{array}$ & $\begin{array}{l}\text { Cost reduction may result in productivity loss } \\
\text { High productivity reduces unit costs but may } \\
\text { require high investments }\end{array}$ \\
\hline Value of assets & $\begin{array}{l}\text { On: Positive } \\
\text { Of: Positive }\end{array}$ & $\begin{array}{l}\text { High valued buildings may be a motivation factor } \\
\text { An image of productive workplaces may increase } \\
\text { the value of the building }\end{array}$ \\
\hline CSR & $\begin{array}{l}\text { On: Positive } \\
\text { Of: Positive }\end{array}$ & $\begin{array}{l}\text { Hosithier buildings may increase productivity } \\
\text { High productivity can reduce use of resources } \\
\text { High productivity can reduce use of resources and } \\
\text { increase self-esteem of workers }\end{array}$ \\
\hline
\end{tabular}

For instance, a positive external image of a company can be an important factor for attaining and retaining productive staff and can thereby support productivity development. The other way around, if a company is highly productivity, it might also support an image of being an efficient company. A lean corporate culture can support productivity and high productivity can improve staff's feelings of being attached to a company with a positive corporate identity. Regarding health and safety, a healthy workforce is likely to be more productive than unhealthy workers (Alker, 2014). However, if high productivity is achieved by more intensive work, it might have a negative effect on health and safety by creating risk of stress, accidents and long-term physical degradation of workers (Boxall and Macky, 2014; Ipsen and Jensen, 2012). A further exploration of the added value of healthy workplaces can be found in Van der Voordt and Jensen (2020). A high level of adaptability might reduce potential downtime during changes in production. On the other hand, high productivity might make it more difficult to adapt production processes. 
Reduction of risk can support productivity by ensuring a high uptime for critical supply systems, but increased productivity achieved by implementing novel methods might create new unknown risks. Reducing cost may have a negative effect on productivity, when resources are taken away, or when cheaper but less supportive facilities are introduced, Vice versa, increased productivity may have a direct effect by reducing unit costs. At first sight, it does not make sense to assume a relationship between value of assets and productivity. However, high valued buildings may be a motivation factor and stimulate employees to hard and efficient working. An image of productive workplaces may increase the value of the building.

Nielsen et al. (2017, p. 260) summarise the benefits of sustainability from various studies in four points with the first being "Increased productivity". Healthier buildings and better designed workplaces result in increased employee satisfaction and hence increased productivity. High productivity can reduce use of resources at least relatively in a company. However, if higher productivity leads to lower price and increased consumption on a societal level, this might counteract the reduced resource use for each produced unit. Other issues of Corporate Social Responsibility (CSR) can add to improved work conditions. According to Haynes et al. (2017, p. 229), workers are more productive and creative in a 'happy' environment. Increased productivity by working efficiently and reduced use of resources fits with CSR and contributes to sustainability as well.

\section{Conclusions and further research}

The findings show that FM and CREM can contribute to improved business productivity in many different ways and within all five activity areas. FM and CREM can most directly contribute to improved labour productivity by appropriate space and workplace management that supports work and organisational activities. This is also by far the most researched activity area. Portfolio management and project management can mostly contribute by providing appropriate location, adjacency relations between different parts of the organisation and by supporting process flow and logistics. Property management can contribute to productivity by ensuring business continuity and comfortable indoor climate. Service management can contribute by relieving staff from trivial tasks by efficient services and by providing exiting experiences.

It can also be concluded that the variety of people (personalities, work styles) and work processes (concentration and communication, individual and team work) require a mixture of different settings that enable concentration, individual work with informal contact to colleagues, collaboration in project teams, different types of meetings and relaxation, with particular attention to find a solution for the tension between opportunities for communication and concentration. Haynes (2007b) suggests to design both common areas ('commons') to interact with other group members, and 'caves' to allow office workers to be on their own and being able to concentrate. See Haynes et al. (2017) for an elaborated discussion about how to support both communication and concentration.

The results can be used to obtain a deeper understanding of how FM and CREM can add value to organisations by contributing to improved business productivity. Practitioners can find inspiration on how to contribute to productivity within specific activity areas of FM and CREM. Practitioners may use table 2 and the former findings to start a discussion with FM/CREM staff, HRM and IT 
managers and representatives of employees and to assess whether their own business could benefit from these insights to implement further improvements. Researchers may use table 2 as a starting point for future research.

So far, most studies in this field concerned effects of office environments on labour productivity. Bröchner (2017) concludes that remarkably little research is conducted in the field of total optimisation for office work, taking into account costs and benefits. Studies on productivity could benefit from multi-factor analyses, where the core firm is understood as optimizing inputs including office space, indoor climate and acoustics, IT systems, human resources and support services. An example is Roelofsen (2002), who also estimated profitability, calculating the additional investment and annual costs for ventilation, heating and cooling needed for improving the indoor office climate.

Most publications discuss office workers' or knowledge workers' productivity, without diving more deeply in the needs of different types of office workers, such as researchers, product developers, designers, business administration staff and call centre employees. Alignment to the needs of office occupiers should take into account that people and their work processes can be very different and thus also their needs and preferences. Interestingly, Palvalin et al. (2017) found that self-management skills have a larger impact on the quality and quantity of individual output and the quantity of team output than workplaces for communication and concentration. Improving self-management skills showed to be key to increase the quality of the output. This pleas for a more profound exchange of data and information between HR departments, finance departments and facilities management departments (Haynes et al., 2017).

It is clear that much further research is needed to provide a holistic and empirical evidence based picture of the relationship between FM/CREM and productivity in its widest sense and the relationship between productivity and other value parameters.

\section{References}

Alker, J., Malanca, M., Pottage, C. and O'Brian, R. (2014), Health, Wellbeing \& Productivity in Offices - The next chapter for green building. World Green Building Council.

Appel-Meulenbroek, R. (2014), How to measure added value of CRE and building design. Knowledge sharing in research buildings. $\mathrm{PhD}$ thesis, Eindhoven University of Technology.

Appel-Meulenbroek, R., \& Nardelli, G. (2016), "Innovation and creativity”. Chapter 11, 188-202 in: Jensen and Van der Voordt (2017).

Bakker, I. (2014), Uncovering the secrets of a productive work environment. A journey through the impact of plants and colour, PhD Thesis, Faculty of Industrial Design, TU Delft.

Bakker, I., Van der Voordt, Th., De Boon, J. and Vink, P. (2013), "Red or Blue meeting rooms: does it matter? The impact of colour on perceived productivity, social cohesion and wellbeing", Facilities 31(1/2), 68-83.

Bakker, I. and Van der Voordt, T. (2010), “The influence of plants on productivity”, Facilities, 28, (9/10), 416-439.

Barrett, L.E. (2016), The Effect of Workspace Layout on Individual Perceptions of Creativity Across Generational Cohorts. PhD thesis. Minneapolis: Walden University. 
Boerstra, A. C., Loomans, M. G. L. C. and Hensen, J. L. M. (2014) "Personal control over indoor climate and productivity", Proceedings of Indoor Air 2014, 7-12 July 2014, Hongkong, China.

Bommer, W.H., Johnson, J.L., Rich, G.A., Podsakoff, P.M. and MacKenzie, S.B. (1995), "On the interchangeability of objective and subjective measures of employee performance: a metaanalysis", Personnel Psychology 48(3), 587-605.

Boxall, P. and Macky. K. (2014). "High-Involvement Work Processes, Work Intensification and Employee Well-Being”, Work, Employment and Society, 28(6), pp. 963-984.

Brill, M. and Weidemann, S. (2001), Disproving widespread myths about workplace Design. Jasper, IN: Kimball International.

Bröchner, J. (2017), "Measuring the Productivity of Facilities Management", Journal of Facilities Management 15(3), 285-301.

Candido, C., Thomas, L., Haddad, S., Zhang, F., Mackey, M. and Ye, W. (2019), "Designing activity-based workspaces: satisfaction, productivity and physical activity", Building Research \& Information, 47(3), 275-289.

Chadburn, A., Smith, J. and Milan, J. (2017), "Productivity drivers of knowledge workers in the Central london office environment", Journal of Corporate Real Estate 19(2), pp. 66-79.

Clements-Croome, D. (ed) (2018), Creating the productive workplace. London: Routledge, 3d edition.

Curvelo Magdaniel, F., De Jonge, H. and Den Heijer, A. (2018), "Campus development as catalyst for innovation", Journal of Corporate Real Estate 20(2), 84-102.

De Been, I., and Beijer, M. (2014), "The influence of office type on satisfaction and perceived productivity support", Journal of Facilities Management, 12(2), 142-157.

De Been, I., Van der Voordt. T. and Haynes, B. (2017), "Productivity”. Chapter 9, 140-144 in: Jensen and van der Voordt (2017).

De Dear, R.J., Akimoto, T., Arens, E.A., Brager, G., Candido, C., Cheong, K.W.D., Li, B., Nishihara, N., Sekhar, S.C., Tanabe, S., Toftum, J., Zhang, H. and Zhu, Y. (2013), "Progress in thermal comfort research over the last twenty years", Indoor Air 23(6), pp. 442-461.

De Paoli, D., Sauer, E., and Ropo, A. (2017). The spatial context of organizations: Critique of 'creative workspaces', Journal of Management \& Organization, 1-22.

Ekstrand, M. and Damman, S. (2016), "Front and backstage in the workplace: an explorative case study on activity based working and employee perceptions of control over work-related demands", Journal of Facilities Management 14(2), 188-202.

Fassoulis, K. and Alexopoulos, N. (2015), "The workplace as a factor of job satisfaction and productivity", Journal of Facilities Management, 13(4), 332-349.

Frankema, E. H. P. (2003), Kantoorinnovatie in economisch perspectief. Delft: Center for People and Buildings.

Gensler (2005), These four walls: The real British Office. London: Gensler.

Gensler (2019), U.S. Workplace Survey 2019. Gensler Research Institute.

Groen, B., Van der Voordt, T. Ypma, L. \& Hoekstra, B. (2020), "Impact of employee satisfaction with facilities on perceived productivity support", Journal of Facilities Management, 17(5), 442-462.

Haapakangasa, A., Hallmana, D.M., Mathiassena, S.E. and Jahnckea, E. (2018), "Self-rated productivity and employee well-being in activity-based offices: The role of environmental perceptions and workspace use", Building and Environment 145, 115-124.

Halkos, G. and Bousinakis, B. (2010), "The effect of stress and satisfaction on productivity", International Journal of Productivity and Performance Management, 59(5), 415-431. 
Harris, R. (2019), "Defining and measuring the productive office", Journal of Corporate Real Estate 21(1), 55-71.

Haynes, B. (2007a), "Office productivity: a theoretical framework", Journal of Corporate Real Estate 9(2), 97-110.

Haynes, H.P. (2007b), "The impact of the behavioural environment on office productivity", Journal of Facilities Management, 5(3), 158-171.

Haynes, H.P., Nunnington, N. and Eccles, T. (2017), "Productivity: how CREAM can support improved business productivity". Chapter 11 in: Barry P. Haynes, Nick Nunnington and Timothy Eccles: Corporate Real Estate Asset Management - Strategy and Implementation. Second edition. Routledge, Oxfordshire, UK.

Herzberg, F. (1968), "One More Time: How Do You Motivate Employees?", Harvard Business Review 46(1), 53-62.

Horr, Y.A., Arif, M., Kaushik, A., Mazroei, A., Katafygiotou, M. and Elsarrag, E. (2016), "Occupant productivity and office indoor environment quality: A review of the literature", Building and Environment 105, 369-389.

Ipsen, C., and Jensen, P.L. (2012), "Organizational options for preventing work-related stress in knowledge work", International Journal of Industrial Ergonomics, 42(4), 325-334.

ISO (2012a): Societal security - Business continuity management systems - Requirements. International Standard IS0 22301. International Organization for Standardization.

ISO (2012b): Societal security - Business continuity management systems - Guidance. International Standard ISO 22313. International Organization for Standardization.

ISS (2018), Future of Service Management. ISS Vision 2020. White Book.

Jensen, P.A. (2008, Facilities Management for Students and Practitioners. Centre for Facilities Management - Realdania Research, DTU Management Engineering, 2008.

Jensen, P.A. and Nielsen, H.J. (2020), "How can knowledge workplaces be optimised by new layout and technology?" Transdisciplinary Workplace Research Conference (forthcoming).

Jensen, P.A. and Redlein, A. (2017), "Risk”, Chapter 12, pp. 207-221 in Jensen and van der Voordt (2017).

Jensen, P.A. and van der Voordt, T. (eds.) (2017), Facilities Management and Corporate Real Estate Management as Value Drivers: How to Manage and Measure Adding Value. Routledge, Oxfordshire, UK.

Kaczmarczyk. S., Barber, C., Vega, G., Simpson, G.T., Thormalen, A., Cohn, D., Michael, W. and Shore, J. (2001), People and the Workplace. GSA Office of Governmentwide Policy, Washington DC.

Karakolis, T. and Callaghan, J. P. (2014) "The impact of sit-stand office workstations on worker discomfort and productivity: A review", Applied Ergonomics 45, 799-806.

Leonard, D. and Swap, W.C. (2005), When Sparks Fly: Harnessing the Power of Group Creativity. Boston: Harvard Business Review Press.

Maarleveld, M. and De Been, I. (2011), "The influence of the workplace on perceived productivity", European Facility Management Conference, Conference Paper, May 2011.

Mahoney, J.M., Kurczewski, N.A. and Froede, E.W. (2015), "Design method for multi-user workstations utilizing anthropometry and preference data", Applied Ergonomics 46, Part A (0), 60-66.

Martijn C. V., Galetzka, M., Mobach, M.P., van Hagen, M. and Pruyn, AT.H. (2018) "Cleanliness unravelled: a review and integration of literature". Journal of Facilities Management 16(4), $429-451$ 
Maslow, A.H. (1943), "A theory of human motivation", Psychological Review 50(4), 370-396.

Mesthrige, J.W. and Chiang, Y.H. (2019), "The impact of new working practices on employee productivity. The first exploratory study in Asia", Journal of Facilities Management 17(2), 122141.

Mosbech, K. (2004), Workspace: organizational goals \& physical environments. Book published by the author.

Nappi, I., De Campos Ribeiro, G. and Cochard, N. (2020), "The interplay of stress and workspace attachment on user satisfaction and workspace support to labour productivity", Journal of Corporate Real Estate, forthcoming.

Nardelli, G. (2017), "Innovation dialectics: An extended process perspective on innovation in services", Service Industries Journal, 37(1), 1-26.

Nardelli, G., and Broumels, M. (2018), "Managing innovation processes through value cocreation: A process case from business-to-business service practise", International Journal of Innovation Management, 22(03), 1850030.

Nielsen, S.B., Junghans, A. and Jones. K. (2017), "Sustainability”. Chapter 15, 259-275, in: Jensen and Van der Voordt (2017).

OECD (2001), Measuring Productivity - OECD Manual: Measurement of Aggregate and Industry-level Productivity Growth. Paris: OECD.

Olson, J. (2002), "Research about office workplace activities important to US business - and how to support them", Journal of Facilities Management 1(1), 31-47.

Oseland, N., Marmot, A., Swaffer, F. and Ceneda, S. (2011), "Environments for successful interaction", Facilities 29 (1/2), 50-62.

Palvalin, M., Van der Voordt, T. and Jylhä, T. (2017), "The impact of workplaces and selfmanagement practices on the productivity of knowledge workers", Journal of Facilities Management 15(4), 423-438.

Pine, J. and Gilmore, J. (1999), The Experience Economy. Boston: Harvard Business School Press, Boston

Porter, M.E. (2016). "Location, Competition, and Economic Development: Local Clusters in a Global Economy". Economic Development Quarterly 14(1), 15-34.

Poursafar, Z., Rodrigues, L.L.R and Sriram, K.V. (2019), "Architectural design model for office interior to suit personality types and to enhance productivity", International Journal of Recent Technology and Engineering 8(2), 1916-1921.

Roelofsen, P. (2002), "The impact of office environments on employee performance: the design of the workplace as a strategy for productivity enhancement", Journal of Facilities Management 1(3), 247-264.

Rolfö, L (2018), "Relocation to an activity-based flexible office - Design processes and outcomes", Applied Ergonomics 73, 141-150.

Seddigh, A., Berntson, E., Bodin Danielson, C. and Westerlund, H. (2014), "Concentration requirements modify the effect of office type on indicators of health and performance", Journal of Environmental Psychology 38(June), pp. 167-174.

Sicotte, H., De Serres, A., Delerue, H. and Ménard, V. (2019), "Open creative workspaces impacts for new product development team creativity and effectiveness", Journal of Corporate Real Estate 21(4), 290-306.

Smith, A. and Pitt, M. (2009), 'Sustainable workplaces: Improving staff health and well-being using plants', Journal of Corporate Real Estate 11(1), 52-63. 
Sullivan, J., Baird, G. and Donn, M. (2013), Measuring productivity in the office workplace. Centre for Building Performance Research, Victoria University of Wellington, Wellington, New Zealand.

Taylor, F.W. (1911), The Principles of Scientific Management. New York, NY, US and London, UK: Harper \& Brothers.

Thorn, T. (2019), "Future Facility Manager - Creating culture in a digitized world". Chapter in: Facility Management as a digital change agent - What you need to know about the transformation of FM in the digital age. Danish Facilities Management network.

Van der Voordt, D.J.M. (2003), Costs and benefits of innovative workplace design. Delft: Center for People and Buildings.

Van der Voordt, T. and Jensen, P.A. (2020), "The added value of healthy workplaces - in search for evidence", Conference paper, 2nd Transdisciplinary Workplace Research (TWR) Conference 2020, September 16-19, Frankfurt/Weimar, Germany.

Van der Voordt, T., Brunia, S. and Appel-Meulenbroek, R. (2017), "Satisfaction”. Chapter 5, 6782 in: Jensen and van der Voordt (2017).

Van Meel, J., Martens, Y. and van Ree, H.J. (2010), Planning Office Spaces - a practical guide for managers and designers. Laurence King Publisher.

Van Meel, J. and Stordal, K.B. (2017), Briefing For Buildings - A Practical Guide For Clients and Their Design Teams. ICOP, The Netherlands.

Von Felten, D., Böhm, M. and Coenen, C. (2015), "Multiplier Effects through FM services: A survey-based analysis of added value in FM", European Facility Management Conference EFMC 2015, Glasgow, 2-3 June 2015.

Webster, J. and Watson, R.T. (2002), "Analyzing the past to prepare for the future: writing a literature review, Guest editorial", MIS Quarterly 26(2), 13-23.

Weijs-Perrée, M. (2019), The users' value of business center concepts for knowledge sharing and networking behavior within and between organizations. $\mathrm{PhD}$ thesis Eindhoven University of Technology.

Wright, S. (2017), "What is in the new workplace environment? A consideration of the impact of well-being factors on corporate office provision", Corporate Real Estate Journal 6(4), 373383.

Yang, H., Sutherland, S., Breslau, B. and Caroll, T. (2015), Global corporate real estate trends. Jones Lang Lasalle.

Yunus, E.N. and Ernawati, E. (2018), "Productivity paradox? The impact of office redesign on employee productivity", International Journal of Productivity and Performance Management 67(9), 1918-1939,

Zelenski, J.M, Murphy, S.A. and Jenkins, D.A. (2008), “The Happy-Productive Worker Thesis Revisited, Journal of Happiness Studies 9, 521-537.

Corresponding author: Per Anker Jensen, pank@dtu.dk 